\title{
Ana Clara Torres Ribeiro
}

Somente na liberdade de falarmos uns com os outros é que surge, totalmente objetivo e visivel desde todos os lados, o mundo sobre o qual se fala. Viver num mundo real e falar uns com os outros sobre ele são basicamente a mesma coisa (...). Liberdade - liberdade de partir e começar algo novo e inaudito, liberdade de interagir oralmente com muitos outros e experimentar a diversidade que é a totalidade do mundo, é a substância e o significado de tudo que é politico.

ARENDT, H. A promessa da política. Rio de Janeiro: Difel, 2008. p.185

A comunidade científica brasileira perdeu uma de suas mais brilhantes pensadoras. Além da perda intelectual e política, a presença generosa e o espírito livre de Ana Clara Torres Ribeiro deixam saudades em todos que a conheciam dos muitos lugares por onde ela circulou. Formada em Harmonia pelo Conservatório Brasileiro de Música, concluiu a graduação em Ciências Políticas e Sociais na PUC do Rio de Janeiro em 1967, o Mestrado em Sociologia no IUPERJ em 1977 e o Doutorado em Sociologia na USP em 1988. Sua trajetória profissional foi marcada pela liberdade de partir e começar algo novo sempre que condições precárias e instáveis de trabalho - como em episódios de repressão sob o regime ditatorial - ou seu olhar curioso sobre o mundo lhe impusessem.

Conheci Ana Clara no final dos anos 1970 no decorrer de uma pesquisa sobre a expansão da fronteira na Amazônia, coordenada pela professora Bertha Becker. Poucos anos depois estivemos juntas em outro projeto coordenado pelo professor Milton Santos sobre o meio técnico-científico e a urbanização no Brasil. Nesses anos de convivência no Departamento de Geografia da UFRJ, onde ela também dava aulas de Sociologia Urbana no Programa de Pós-Graduação, éramos sempre surpreendidos pela agudeza de sua reflexão metodológica. Ana Clara tinha uma cabeça que, somente muitos anos depois eu aprendi, veio da música. Harmonia e estrutura lógica se combinavam para pensar totalidades complexas.

Em entrevista concedida à Revista Geosul em novembro de 2010, Ana Clara reconhecia ser uma socióloga, mas não fechada no campo da sociologia. Reconhecia igualmente que o trabalho no Lastro Laboratório da Conjuntura Social: tecnologia e terri- tório - fundado no Instituto de Planejamento Urbano e Regional da UFRJ em 1998, ao lado de orientandos vindos de campos disciplinares tão diversos como a engenharia, a geografia, a arquitetura e urbanismo e as ciências sociais estava ancorado metodologicamente na problemática social, integrando tempo e espaço e buscando compreender novas formas de ação social: quem é que está nas ruas? Como isso está acontecendo? Por que aquilo acontece naquele lugar e não em outro? Interagindo com vários campos do conhecimento através da mediação da cultura, ela desenvolvia uma pedagogia que se insubordinava diante das fronteiras disciplinares.

Nas duas últimas décadas Ana Clara participou ativamente da vida da Anpur, integrando sua diretoria entre 1991 e 1993, época em que Milton Santos esteve na presidência. Dez anos depois, de 2003 a 2005, assumiu outra vez suas funçōes na Associação, sob a presidência de Heloisa Soares de Moura Costa, e em 2009 retornou ao cargo, permanecendo nele até 2011, período em que presidimos a Associação na UFSC. Em maio desse mesmo ano, ela foi eleita presidente da Anpur na Assembleia do XIV Enanpur, realizado no Rio de Janeiro. Atenta à realidade do país, curiosa e inovadora na escuta de múltiplas vozes, Ana Clara questionou e problematizou a crise societária contemporânea no âmbito do pensamento e da ação do planejamento urbano e regional no Brasil. Instigadores e livres para interagir com muitos outros, seus escritos nos ajudam a experimentar e apreender a diversidade do mundo.

Leila Christina Dias

Professora associada da UFSC Presidente da Anpur (2009-2001) 